\title{
Surgical Strategies for Neurological Function Preservation in Severe Brain Contusion
}

\author{
Şiddetli Beyin Kontüzyonunda Nörolojik İşlev Koruma İcin Cerrabi \\ Stratejiler
}

Binghui QIU, Shuxiang XU, Luxiong FANG, Silky CHOTAI, Weiguang LI, Songtao QI

Nanfang Hospital, Southern Medical University, Department of Neurosurgery, Guangzhou, China

Correspondence address: Binghui QIU / E-mail: qiubui@gdvnet.com

\begin{abstract}
AIM: Traditional surgical strategies for severe brain contusion are constantly associated with variable degree of postoperative neurological dysfunction, which is in part attributed to the location and severity of contusion. The purpose of this study was to compare and evaluate these current surgical strategies, with an emphasis on neurological function preservation.

MATERIAL and METHODS: A retrospective review of surgical strategies employed for 142 cases of severe brain contusion was performed. The surgical strategies were stratified into four types, Type I, Simple DC, without resection of contusion; II, Resection of contusion, combined with DC; III, Safe cerebral lobe resection and DC, without resection of contusion; IV, Simple resection of contusion, without decompression. The patients were accordingly separated into four groups.

RESULTS: The favorable prognosis rate in Group I, II and III was higher than Group IV on 6-month follow-up Glasgow Outcome Score (GOS). No significant difference of mortality rate was observed among Group I, II and III ( $p>0.05$ ), but the favorable prognosis rate of Group II was lower than Group I and III ( $\mathrm{p}<0.05)$.

CONCLUSION: Simple DC and safe cerebral lobe resection combined with DC might achieve better therapeutic effect, and could be recommended as the preferred surgical strategies for severe brain contusion.
\end{abstract}

KEYWORDS: Traumatic brain injury, Brain contusion, Decompressive craniectomy, Neurological function preservation

öz

AMAÇ: Beyin kontüzyonu için geleneksel cerrahi stratejiler değişken derecede postoperatif nörolojik disfonksiyonla daima ilişkilidir ve bu kısmen kontüzyonun yeri ve şiddetiyle ilişkili bulunmuştur. Bu çalışmanın amacı, nörolojik işlev koruma vurgulanarak mevcut cerrahi stratejileri karşılaştırmak ve değerlendirmektir.

YÖNTEM ve GEREÇLER: 142 şiddetli beyin kontüzyonu vakası için kullanılan cerrahi stratejilerin retrospektif bir gözden geçirmesi yapılmıştır. Cerrahi stratejiler dört tipe ayrılmıştır:Tip I, Basit DC, kontüzyon rezeksiyonu yapılmadan; II, Kontüzyon rezeksiyonu, DC ile kombine; III Güvenli serebral lop rezeksiyonu ve DC, kontüzyon rezeksiyonu yapılmadan; IV, Basit kontüzyon rezeksiyonu, dekompresyon yapılmadan. Hastalar buna göre dört gruba ayrılmıştır.

BULGULAR: Grup I, II ve III için olumlu prognoz oranı Glasgow Sonuç Skoruna (GOS) göre 6 aylık takipte Grup IV'te daha iyi bulunmuştur. Grup I, II ve III arasında mortalite oranında önemli bir farklılık görülmemiş ( $p>0,05)$ ama Grup II için olumsuz prognoz oranı Grup I ve III'ten daha düşük bulunmuştur $(p<0,05)$.

SONUÇ: Basit DC ve DC ile kombine edilen güvenli serebral lob rezeksiyonu daha iyi terapötik etki sağlayabilir ve şiddetli beyin kontüzyonu için tercih edilen cerrahi stratejiler olarak önerilebilir.

ANAHTAR SÖZCÜKLER: Travmatik beyin hasarı, Beyin kontüzyonu, Dekompresif kraniyektomi, Nörolojik işlev koruma

\section{INTRODUCTION}

Traumatic brain injury with severe contusion is usually characterized by significant encephaledema, medically refractory intracranial hypertension, and progressive neurological dysfunction, which is associated with poor outcomes. Current strategies of both conservative and surgical treatment are mainly based on the escalation principle of intracranial hypertension $(3,4,5,23)$. A variety of surgical strategies has been adopted according to the location, type and severity of the contusion (1). Effective and commonly employed therapies to ameliorate intracranial hypertension include surgical excision of necrotic brain tissue, decompressive craniectomy (DC), or both. However, resection of necrotic brain tissue is always associated with the loss of neurological function to a certain extent. We attempted to address this issue and improved surgical strategies based on the location and severity of contusion, with an emphasis on the preservation of neurological function. 


\section{PATIENTS and METHODS}

\section{Patient characteristics}

A retrospective review of prospectively collected data was performed for a total of 142 patients with acute severe brain contusion admitted between Jan. 2004 and Dec. 2009. Of this, 127 patients were admitted immediately after injury, and 15 were transferred from other hospitals after surgery. There were 92 males and 50 females in the study, and the M/F ratio was 1.84:1. The mean age of patients was 34.3 (range, 12-66 years). The mode of injury included traffic accident (91 cases), fall from height ( 28 cases), and others ( 23 cases). All the cases were diagnosed by clinical presentations and medical imaging. Severe brain contusion was defined as a wide range of unilateral or bilateral scattered high-density hemorrhagic focus and encephaledema on CT scan, with a Glasgow Coma Scale (GCS) score of 3-8 (less than 5 in 46 cases (32.4\%)). 29 patients were complicated with multisystem injuries including bone fracture (19 cases), hemopneumothorax or traumatic pulmonary edema (6 cases), and other injuries (4 cases). Exclusion criteria included the time to admission $>20$ hours, non-traumatic brain lesions (such as tumor, AVM or aneurysm), anticoagulation therapy, concomitant infection, hemophilia, hemolysis, elevated liver enzymes, decreased platelet count, and pregnancy.

\section{Treatment Strategies}

A total of 111 patients with contused tissue $>20 \mathrm{ml}$, severe edema, and cistern compression or midline shift $>5 \mathrm{~mm}$, underwent emergent surgery (6). 15 patients transferred from other hospitals were admitted into the Neurosurgical Intensive Care Unit (NICU) with intensive monitoring, intracranial pressure (ICP) monitoring and conservative treatment. The other 16 patients who did not undergo emergent surgery were also offered conservative treatment, but later presented with exacerbation of unconsciousness, increased intracranial pressure, contusion focus enlargement, or encephaledema development, and were then merited for surgery. A significant increase in contusion was defined as an enlargement of $\geq 30 \%$ of the original size on CT scan (3). Among the 15 transferred patients, 3 patients who developed traumatic cerebral infarction and 1 patient who had delayed intracerebral hematoma underwent reoperation.

Based on the location and severity of contusion, and the principle of neurological function preservation, surgical strategies were classified into four types. The patients were divided into Group I, II, III and IV according to the surgical strategies employed. Type I strategy, for patients with localized contusion in functional area, or mass effect mainly caused by encephaledema, was simple decompressive craniectomy (DC) without resection of the contused tissue. This strategy was mainly applied to brain contusion of the frontal lobe, lateral fissure, post-temporal and eloquent regions of the brain (Figure 1A,B). Type II, for patients with severe and extensive contusion in superficial non-functional area, was resection of contused tissue combined with DC. This strategy was mainly employed for brain contusion of the frontal and temporal lobe (Figure $2 A, B$ ). Type III, for patients with brain contusion in functional area, multiple contusion foci in eloquent regions of the brain, or small intracerebral hematoma, when simple decompression could not completely resolve the intracranial hypertension, was DC combined with resection of safe cerebral lobe such as ipsilateral frontal pole or temporal pole, instead of contusion tissue evacuation. This strategy was mainly employed for contusion in post-frontal, post-temporal, parietal lobe and eloquent regions of the brain (Figure $3 \mathrm{~A}, \mathrm{~B}$ ). Type IV, for patients with severe but localized contusion which was mainly responsible for the mass effect, was surgical excision of the necrotic brain tissue without decompression. This strategy was mainly applied to localized contusion with intracerebral hematoma in unilateral frontal-parietal lobe or temporal-parietal lobe (Figure 4A,B). Decompression was achieved by unilateral or bilateral fronto-temporal standard trauma craniectomy and expanded duraplasty (16).

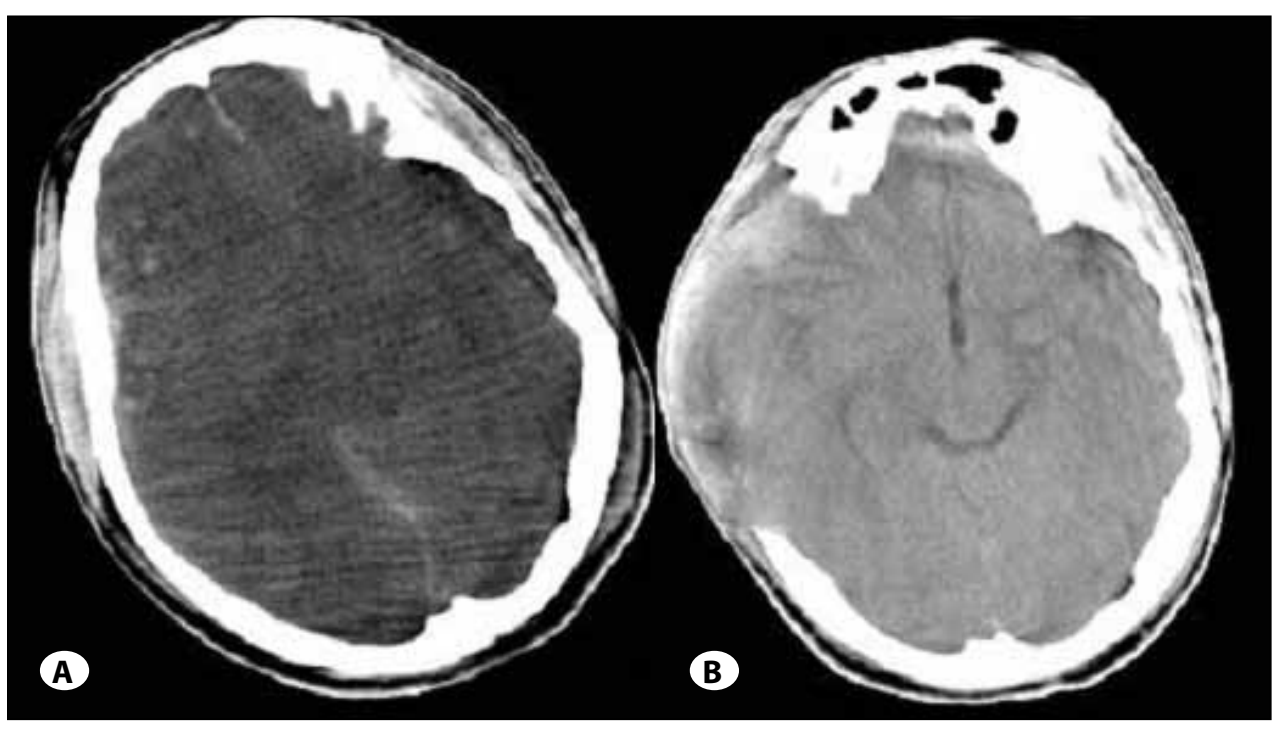

Figure 1: Pre- and postoperative computed tomography (CT) imaging of patient who underwent type I strategy. (A) Preoperative CT scan demonstrating severe contusion in right lateral fissure region and obliterated cisterns.

(B) Postoperative CT scan showing significantly decreased brain edema after decompressive craniectomy (DC). 

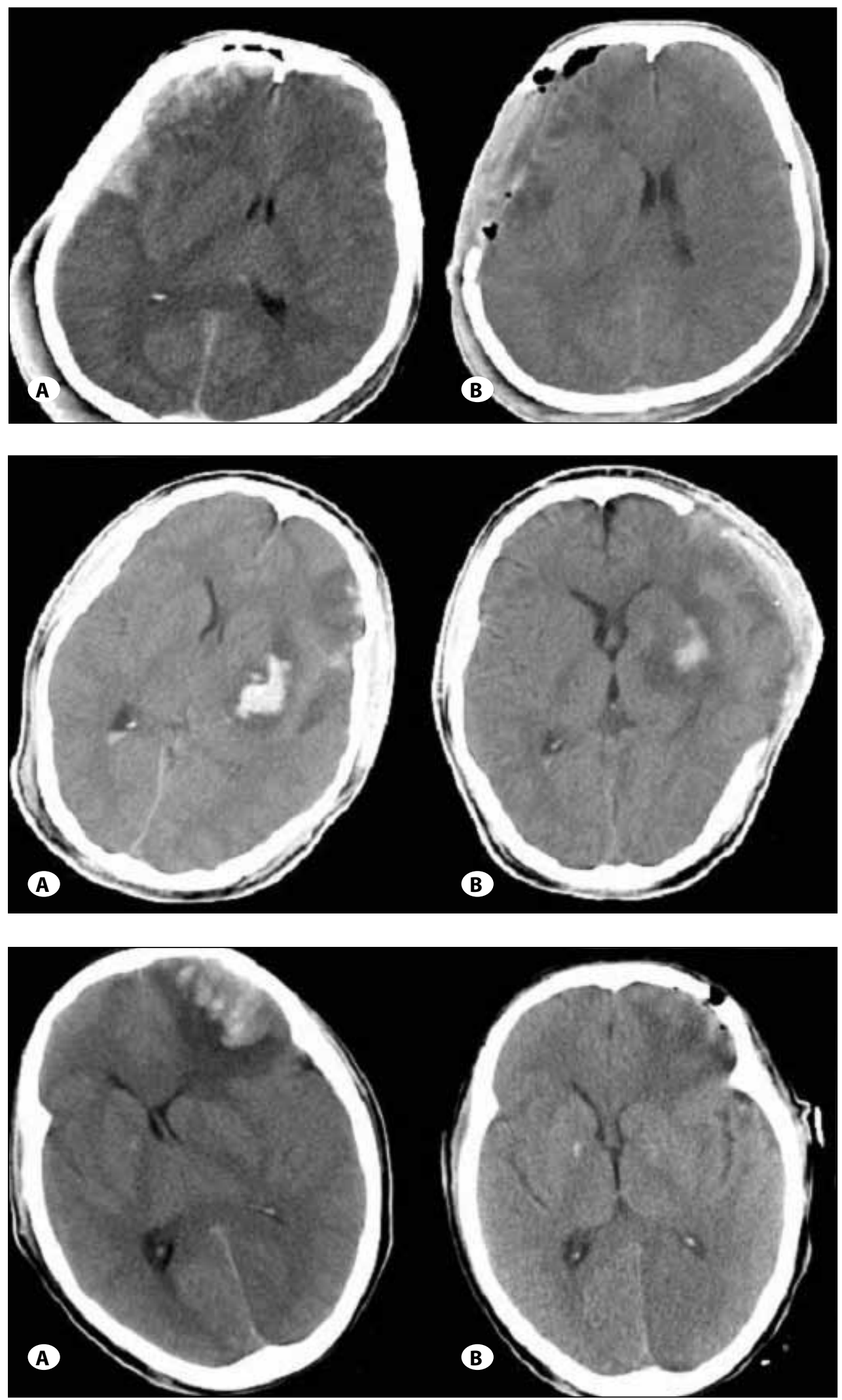

Figure 2: Pre- and postoperative CT scan of patient who underwent type II strategy. (A) Preoperative CT scan showing extensive contusion in right frontal lobe and compressed ventricles. (B) Postoperative CT scan indicating decreased compression of the ventricles after DC combined with resection of the contusion tissue.

Figure 3: Pre-and postoperative computed tomography(CT) scan of type III (A) Preoperative CT scan demonstrating contusion, small hematoma and brain edema in left eloquent regions with compressed ventricles. (B) Postoperative CT scan showing outward shift of the hematoma and decreased compression of ventricles after DC combined with anterior temporal lobe resection.

Figure 4: Pre- and postoperative computed tomography(CT) scan of type IV strategy.

(A) Preoperative CT scan showing contusion of left frontal lobe.

(B) The contusion was resected on postoperative $\mathrm{CT}$. 
All the patients were transferred into NICU after surgery. Conservative treatment included early-stage tracheostomy, ICP monitoring, preservation of effective cerebral perfusion pressure (CPP), parenteral resuscitation therapy, prevention of infection and gastrointestinal bleeding, early-stage enteral nutrition therapy, awaking therapy, and early-stage rehabilitation. All the cases underwent $C T$ scan reexamination 24-72 hours after the surgery.

\section{Complications and Prognosis Evaluation}

Postoperative complications such as delayed hematoma, hematoma enlargement, cerebral infarction, encephalocele, intracranial infection, hydrocephalus, incisional herniation (brain herniation through the incision) and CSF leakage were observed. The complications in each group were analyzed and compared.

Neurological outcome was assessed for each patient at 6-month follow-up based on the Glasgow Outcome Scale (GOS). The GOS score of patients was determined respectively by two experienced attending trauma surgeons who did not participate in the surgical treatment of these patients,

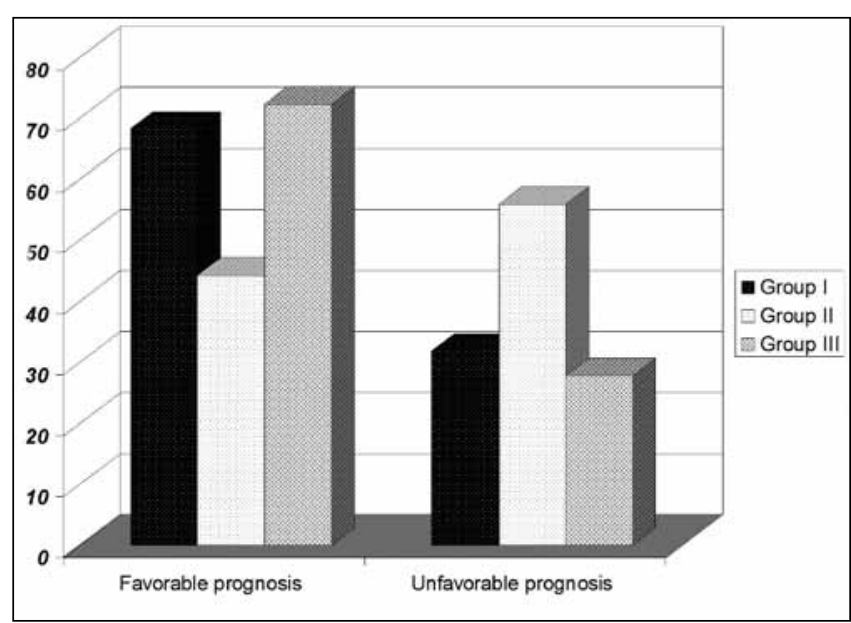

Figure 5: The figure compares therapeutic effect in Group I III (\%). The rate of favorable prognosis was lower in Group II (44.2\%), compared to Group I (68.2\%) and Group III (72.2\%). via face-to-face interviews with patients, their next of kin or caregivers in our hospital, or via telephone interview when the patients were unable to come back for a follow-up. As the mortality of Group I, II and III showed no significant difference, the patients in these groups were further classified into the favorable prognosis group and poor prognosis group. The favorable prognosis group was defined as good recovery (GOS 5) and moderate disability (GOS 4) on GOS; and the poor prognosis group as severe disability (GOS 3), vegetative status (GOS 2) (persistent coma more than three months) and death (GOS 1).

\section{Statistical analysis}

Statistical analysis was performed using commercially available software SPSS 18.0 for Windows. The Pearson chisquare test was performed to compare the complications and prognosis in each group.

\section{RESULTS}

There were 44 patients $(31.0 \%)$ (1 case transferred from other hospital) of Type I, 52 (36.6\%) (9 transferred) of Type II, 36 (25.3\%) of Type III and 10 (7.0\%) (5 transferred) of Type IV strategy. A total of $113(79.6 \%)$ patients underwent unilateral surgery, and 29 (20.4\%) underwent bilateral surgery. Postoperative complications included delayed hematoma, hematoma enlargement, cerebral infarction, encephalocele, intracranial infection, hydrocephalus, incisional herniation (cerebral herniation through the incision), and CSF leakage. The incidence of cerebral infarction was highest in Group IV $\left(X^{2}=11.471, v=3, P=0.009\right)$. No significant difference was found regarding the other complications among the four groups. The overall rate of complications in Group IV was higher than other groups, and the difference was statistically significant $\left(X^{2}=12.906, v=3, P=0.005\right)$ (Table I).

On 6-month follow up, there were 23 patients (16.2\%) with good recovery, 59 (41.5\%) with moderate disability, 22 (15.5\%) with severe disability, 23 (16.2\%) in vegetative status and 15 patients $(10.6 \%)$ who had died. Patients with good recovery and moderate disability scores were classified into favorable prognosis group, and those who had severe

Table I: Comparison of the Complications in Four Groups [n (\%)]

\begin{tabular}{|c|c|c|c|c|c|c|c|c|}
\hline Group & Cases & $\begin{array}{c}\text { Delayed } \\
\text { hematoma or } \\
\text { hematoma } \\
\text { enlargement }\end{array}$ & $\begin{array}{l}\text { Cerebral } \\
\text { infarction }\end{array}$ & Encephalocele & $\begin{array}{l}\text { Intracranial } \\
\text { infection }\end{array}$ & Hydrocephalus & $\begin{array}{c}\text { Incisional } \\
\text { hernia or CSF } \\
\text { leakage }\end{array}$ & $\begin{array}{l}\text { Overall } \\
\text { rate }\end{array}$ \\
\hline 1 & 44 & $6(13.6)$ & $5(11.4)$ & $4(9.1)$ & $1(2.3)$ & $3(6.8)$ & $1(2.3)$ & $20(45.5)$ \\
\hline II & 52 & $3(5.8)$ & $6(11.5)$ & $2(3.9)$ & $1(1.9)$ & $4(7.7)$ & $0(0.0)$ & $16(30.8)$ \\
\hline III & 36 & $4(11.1)$ & $4(11.1)$ & $2(5.6)$ & $0(0.0)$ & $3(8.3)$ & $0(0.0)$ & $13(36.1)$ \\
\hline IV & 10 & $1(10.0)$ & $5(50.0)$ & $1(10.0)$ & $0(0.0)$ & $1(10.0)$ & $1(10.0)$ & $9(90.0)$ \\
\hline \multicolumn{2}{|c|}{$x^{2}$} & 1.749 & 11.471 & 1.369 & 0.993 & 0.142 & 6.810 & 12.906 \\
\hline \multicolumn{2}{|c|}{$P$} & 0.626 & 0.009 & 0.713 & 0.803 & 0.986 & 0.078 & 0.005 \\
\hline
\end{tabular}

The incidence of cerebral infarction was the highest in Group IV ( $\left.X^{2}=11.471, v=3, P=0.009\right)$. No significant difference was found in other complications among the four groups. The overall rate of complications in Group IV was higher than the other groups $\left(X^{2}=12.906, v=3, P=0.005\right)$. 
Table II: Comparison of the Prognosis in Four Groups [n (\%)]

\begin{tabular}{|c|c|c|c|c|c|c|}
\hline Group & Cases & Good recovery & Moderate disability & Severe disability & Vegetative status & Death \\
\hline I & 44 & $10(22.7)$ & $20(45.5)$ & $5(11.4)$ & $6(13.6)$ & $3(6.8)$ \\
\hline II & 52 & $5(9.6)$ & $18(34.6)$ & $12(23.1)$ & $12(23.1)$ & $5(9.6)$ \\
\hline III & 36 & $8(22.2)$ & $18(50.0)$ & $4(11.1)$ & $3(8.3)$ & $3(8.3)$ \\
\hline IV & 10 & $0(0.0)$ & $3(30.0)$ & $1(10.0)$ & $2(20.0)$ & $4(40.0)$ \\
\hline & & 5.937 & 2.914 & 3.616 & 3.772 & 10.064 \\
\hline
\end{tabular}

Group IV demonstrated the highest mortality rate ( $\left.X^{2}=10.064, v=3, P=0.018\right)$. No significant difference of mortality rate was observed among Group I, II and III $(P>0.05)$.

Table III: Comparison of the Therapeutic Effect in Group I-III [n (\%)]

\begin{tabular}{|c|c|c|c|}
\hline Group & Cases & Favorable prognosis & Unfavorable prognosis \\
\hline I & 44 & $30(68.2)$ & $14(31.8)$ \\
II & 52 & $23(44.2)$ & $29(55.8)$ \\
III & 36 & $26(72.2)$ & $10(27.8)$
\end{tabular}

The rate of favorable prognosis was lower in Group II (44.2\%), compared to Group I (68.2\%) and Group III (72.2\%) $\left(X^{2}=8.843, v=2, P=0.012\right)$.

disability or vegetative status or had died were classified into the unfavorable prognosis group. Group IV demonstrated the highest mortality rate, and the difference was statistically significant $\left(X^{2}=10.064, v=3, P=0.018\right)$ (Table II). No significant difference of mortality rate was observed among Group I, II and III ( $p>0.05)$. However, the rate of favorable prognosis was lower in Group II (44.2\%), compared to Group I (68.2\%) and Group III (72.2\%) (Figure 5), and the difference was statistically significant $\left(X^{2}=8.843, v=2, P=0.012\right)$ (Table III).

\section{DISCUSSION}

Severe brain contusion is often associated with nonhemorrhagic mass effect that progresses rapidly within 12 to 48 hours after injury. The mechanisms underlying such a rapid progression of mass effect cannot be fully explained by classic concepts of vasogenic and cytotoxic brain edema $(19,21,22)$. The breakdown of debris of membrane and cytoplasmic structures generates high osmolality within the contused brain tissue. The high osmotic potential across the central and peripheral areas results in water accumulation in the contused tissue, which is postulated to be the main cause of rapid progression $(18,19)$. Intracranial hypertension and low perfusion pressure secondary to severe brain contusion may result in cerebral ischemia, brain damage and death (15, 20). It has been purported that surgical intervention should be considered as early as possible when surgical indications are met $(24,26,27)$. However, the surgical strategy employed varies depending on the institutional experience. Although controversial, early DC is still considered by many authors to be effective in preventing secondary brain damage, reducing edema formation, and achieving a better outcome (7, 9, $13,25)$. Kawamata et al. believe that early massive edema is caused by brain contusion, and surgical excision of the necrotic tissue provides satisfactory control of progressive elevation in ICP and clinical deterioration (17-19).
Before 2007, the surgical strategy for acute severe brain contusion in our hospital was primarily resection of the contused tissue followed by DC, which was consistent with Rubiano et al. and Kawamata et al. This study indicated that resection of contused tissue combined with DC (Type II) was the most commonly employed strategy (36.6\%), mainly suitable for contusion located in a relatively nonfunctional area. Although the mortality rate $(9.6 \%)$ decreased significantly under this type of strategy, the resected region was constantly associated with a certain degree of neurological dysfunction (55.8\%), including mild symptoms such as memory deterioration, affective disorder, poor expression or response retardation, as well as severe symptoms such as dyskinesia or even hemiplegia, and aphasia $(12,14,28,29)$. It was probably not suitable for all the cases.

Then how about treating severe brain contusion without resection of the necrotic tissue? As it has been generally acknowledged that bone flap decompression can significantly relieve intracranial hypertension in severe craniocerebral injury and improve therapeutic outcome $(2,29)$, we first tried to perform simple DC (Type I) in some cases of located contusion around lateral fissure, without evacuation of the necrotic tissue, to avoid postoperative angiospasm, cerebral ischemia and impairment of neurological function such as aphasia. Satisfactory control of intracranial hypertension and favorable outcome was achieved, and we intended to extend this strategy to localized contusion with relatively mild encephaledema in functional area. The favorable prognosis rate of this group reached $68.2 \%$, and mortality rate decreased to $6.8 \%$. However, simple DC could still not completely ameliorate intracranial hypertension in some patient and the resection of the safe cerebral lobe was therefore contemplated (Type III). This surgical strategy was employed for the treatment of severe brain contusion in the functional area, 
the lateral fissure region, and eloquent regions, where simple DC could not suffice to control intracranial hypertension. The resection of prefrontal or anterior temporal lobe not only relieved intracranial hypertension, but also increased intracranial space $(10,30)$, avoiding further exacerbation of functional impairment. The mortality rate of this group was only $8.3 \%$, and the favorable prognosis rate reached $72.2 \%$.

Simple resection of contused tissue without DC (Type IV) was employed in a total of 10 patients ( 5 cases were transferred from other hospitals). The incidence of traumatic cerebral infarction and secondary intracranial hypertension was significantly higher in this group, which led to an increase of the mortality rate (40.0\%). Encephaledema and cerebral ischemia secondary to acute severe brain contusion is an important pathophysiological mechanism (17-19), and difficult to prevent by simple resection of necrotic brain tissue $(6,8,9)$. This strategy is therefore only suitable for patients with localized contusion and mild encephaledema, and may not be recommended for routine clinical application.

\section{CONCLUSION}

The aim of surgical intervention in acute brain contusion is to control malignant intracranial hypertension, to preserve cerebral perfusion, and to protect neurological functions (3, 11 , 24). Simple DC (Type I), contused tissue resection with DC (Type II) and safe cerebral lobe resection with DC (Type III) are all able to achieve the aim of controlling ICP, preserving cerebral perfusion and decreasing the mortality rate. However, simple DC (Type I) and safe cerebral lobe resection with DC (Type III) seemed to be better than contused tissue resection with DC (Type II) for the preservation of neurological function in this study. These two strategies might achieve a better therapeutic effect, and could be recommended as the preferred surgical strategies for severe brain contusion.

\section{REFERENCES}

1. Aarabi B, Hesdorffer DC, Simard JM, Ahn ES, Aresco C, Eisenberg HM, McCunn M, Scalea T: Comparative study of decompressive craniectomy after mass lesion evacuation in severe head injury. Neurosurgery 64: 927-939, 2009

2. Ahmadi SA, Meier U, Lemcke J: Detailed long-term outcome analysis after decompressive craniectomy for severe traumatic brain injury. Brain Injury 24: 1539-1549, 2010

3. Alahmadi $\mathrm{H}$, Vachhrajani S, Cusimano MD: The natural history of brain contusion: An analysis of radiological and clinical progression - clinical article. Journal of Neurosurgery 112: 1139-1145, 2010

4. Brain Trauma Foundation AAoNS, Joint Section on Neurotrauma and Critical Care: Guidelines for the management of severe head injury. J Neurotrauma 13: 641-734, 1996

5. Bratton SL, Chestnut RM, Ghajar J, McConnell Hammond FF, Harris OA, Hartl R, Manley GT, Nemecek A, Newell DW, Rosenthal G, Schouten J, Shutter L, Timmons SD, Ullman JS, Videtta W, Wilberger JE, Wright DW: Guidelines for the management of severe traumatic brain injury. VIII. Intracranial pressure thresholds. J Neurotrauma 24 Suppl 1: S55-58, 2007
6. Bullock MR, Chesnut R, Ghajar J, Gordon D, Hartl R, Newell DW, Servadei F, Walters BC, Wilberger J: Surgical management of traumatic parenchymal lesions. Neurosurgery 58:25-46; discussion Si-iv, 2006

7. Chibbaro S, Tacconi L: Role of decompressive craniectomy in the management of severe head injury with refractory cerebral edema and intractable intracranial pressure. Our experience with 48 cases. Surgical Neurology 68:632-638, 2007

8. Compagnone C, Murray GD, Teasdale GM, Maas Al, Esposito D, Princi P, D'Avella D, Servadei F: The management of patients with intradural post-traumatic mass lesions: A multicenter survey of current approaches to surgical management in 729 patients coordinated by the european brain injury consortium. Neurosurgery 57:1183-1192; discussion 11831192, 2005

9. Compagnone C, Murray GD, Teasdale GM, Maas Al, Esposito D, Princi P, D'Avella D, Servadei F: The management of patients with intradural post-traumatic mass lesions: A multicenter survey of current approaches to surgical management in 729 patients coordinated by the european brain injury consortium. Neurosurgery 61:232-240; discussion 240-231, 2007

10. Eberle BM, Schnuriger B, Inaba K, Gruen JP, Demetriades D, Belzberg H: Decompressive craniectomy: Surgical control of traumatic intracranial hypertension may improve outcome. Injury 41: 894-898, 2010

11. Flanagan SR, Cantor JB, Ashman TA: Traumatic brain injury: Future assessment tools and treatment prospects. Neuropsychiatr Dis Treat 4: 877-892, 2008

12. Honeybul S, Ho KM, Lind CRP, Corcoran T, Gillett GR: The retrospective application of a prediction model to patients who have had a decompressive craniectomy for trauma. Journal of Neurotrauma 26: 2179-2183, 2009

13. Howard JL, Cipolle MD, Anderson M, Sabella V, Shollenberger D, Li PM, Pasquale MD: Outcome after decompressive craniectomy for the treatment of severe traumatic brain injury. Journal of Trauma Injury Infection and Critical Care 65: 380-385, 2008

14. Huang APH, Tu YK, Tsai YH, Chen YS, Hong WC, Yang CC, Kuo LT, Su IC, Huang SH, Huang SJ: Decompressive craniectomy as the primary surgical intervention for hemorrhagic contusion. Journal of Neurotrauma 25: 1347-1354, 2008

15. Jiang JY, Gao GY, Li WP, Yu MK, Zhu C: Early indicators of prognosis in 846 cases of severe traumatic brain injury. Journal of Neurotrauma 19:869-874, 2002

16. Jiang JY: Recent advance and current status of management of head trauma in china. Chin J Traumatol 11:222-224, 2008

17. Katayama Y, Kawamata T: Edema fluid accumulation within necrotic brain tissue as a cause of the mass effect of cerebral contusion in head trauma patients. Brain Edema 12:323-327, 2003

18 Kawamata T, Katayama Y: Surgical management of early massive edema caused by cerebral contusion in head trauma patients. Brain Edema XIII: 3-6, 2006 
19. Kawamata T, Mori T, Sato S, Katayama Y: Tissue hyperosmolality and brain edema in cerebral contusion. Neurosurg Focus 22: E5, 2007

20. Langfitt TW, Tannanbaum HM, Kassell NF: The etiology of acute brain swelling following experimental head injury. J Neurosurg 24: 47-56, 1966

21. Marmarou A, Signoretti S, Ayg G, Fatouros P, Portella G: Traumatic brain edema in diffuse and focal injury: Cellular or vasogenic? Brain Edema XIII: 24-29, 2006

22. Naredi S, Eden E, Zall S, Stephensen H, Rydenhag B: A standardized neurosurgical neurointensive therapy directed toward vasogenic edema after severe traumatic brain injury: Clinical results. Intensive Care Med 24: 446-451, 1998

23. Nilsson $P$, Enblad $P$, Chambers I, Citerio G, Fiddes $H$, Howells T, Kiening K, Ragauskas A, Sahuquillo J, Yau YH, Contant C, Piper I: Survey of traumatic brain injury management in european brain-it centres year 2001. Acta Neurochirurgica (Supplement) 95: 51-53, 2005

24. Rossi S, Castioni CA: Guidelines for the management of severe traumatic brain injury: Still needed? Minerva Anestesiol 74: 579-581, 2008

25 Rubiano AM, Villarreal W, Hakim EJ, Aristizabal J, Hakim F, Diez JC, Pena G, Puyana JC: Early decompressive craniectomy for neurotrauma: An institutional experience. Ulus Travma Acil Cerrahi Derg 15(1):28-38, 2009
26. Rusnak M, Janciak I, Majdan M, Wilbacher I, Mauritz W, Austrian Severe TBISI: Severe traumatic brain injury in Austria vi: Effects of guideline-based management. Wiener Klinische Wochenschrift 119: 64-71, 2007

27. Wang MC, Temkin NR, Deyo RA, Jurkovich GJ, Barber J, Dikmen S: Timing of surgery after multisystem injury with traumatic brain injury: Effect on neuropsychological and functional outcome. Journal of Trauma Injury Infection and Critical Care 62: 1250-1258, 2007

28. Warden DL, Gordon B, McAllister TW, Silver JM, Barth JT, Bruns J, Drake A, Gentry T, Jagoda A, Katz DI, Kraus J, Labbate LA, Ryan LM, Sparling MB, Walters B, Whyte J, Zapata A, Zitnay G: Guidelines for the pharmacologic treatment of neurobehavioral sequelae of traumatic brain injury. J Neurotrauma 23:1468-1501, 2006

29. Williams RF, Magnotti LJ, Croce MA, Hargraves BB, Fischer PE, Schroeppel TJ, Zarzaur BL, Muhlbauer M, Timmons SD, Fabian TC: Impact of decompressive craniectomy on functional outcome after severe traumatic brain injury. Journal of Trauma Injury Infection and Critical Care 66: 1570-1576, 2009

30. Yatsushige $H$, Takasato $Y$, Masaoka H, Hayakawa T, Otani N, Yoshino $Y$, Sumiyoshi K, Sugawara T, Miyawaki H, Aoyagi C, Takeuchi S, Suzuki G: Prognosis for severe traumatic brain injury patients treated with bilateral decompressive craniectomy. Brain Edema XIV 106:265-270, 2010 